\title{
A Taxonomy as a Vehicle for Learning
}

\author{
Cornelia Brodahl \\ University of Agder, \\ Kristiansand, Norway
}

Cornelia.Brodahl@uia.no

\author{
Bjørn Smestad \\ Oslo University College, \\ Oslo, Norway
}

\author{
Bjorn.Smestad@lui.hio.no
}

\begin{abstract}
In this article, we describe the development of a classification system providing a framework for analysis of, and communication about, a subgroup of learning objects. The objects we consider are highly visual, animated, interactive, and mathematics-related, and we call them VaniMaps. Secondly, we discuss the use of the system.

In the first phase, the development was based on literature studies and discussions on examples of VaniMaps. In the second phase, the classification system was tested by students and their responses were analyzed to identify possible improvements. Now, the system is developed further based on experience gained while using it for different purposes.

We see several possible uses of the classification system, or selected parts of it: (a) to facilitate communication between the orderer and the developer, (b) to initiate discussions on VaniMaps in teacher education, (c) to analyze and choose between VaniMaps for teaching and learning activities, and (d) to establish a database for VaniMaps labeled using classification statements. We will discuss all these uses and especially emphasize the use in teacher education, illustrated with a case study.
\end{abstract}

Keywords: classification, discussion, evaluation, learning object, mathematics, mathematics education, statements, taxonomy, teacher education, VaniMaps.

\section{Introduction}

This paper has two goals. The first goal is to propose a method for developing a taxonomy of learning objects. This will be discussed in Part A. The second goal is to investigate how such a taxonomy can be used to inform clients. This will be discussed in Part B. In particular, we will discuss a case study in which we use the classification system to foster students' discussion in a university setting.

Material published as part of this publication, either on-line or in print, is copyrighted by the Informing Science Institute. Permission to make digital or paper copy of part or all of these works for personal or classroom use is granted without fee provided that the copies are not made or distributed for profit or commercial advantage AND that copies 1) bear this notice in full and 2) give the full citation on the first page. It is permissible to abstract these works so long as credit is given. To copy in all other cases or to republish or to post on a server or to redistribute to lists requires specific permission and payment of a fee. Contact Publisher@InformingScience.org to request redistribution permission. 


\section{Part A. Development of a Classification System}

\section{Research and Development Issues}

In the research literature, there is a wealth of criteria for assessing different kinds of digital learning materials, tailored to various, often theoretical, purposes. In our project, we wanted to create a list of classification statements suitable for different practical purposes, noticeably the communication about the materials.

One of the authors has many years of experience in programming, including developing learning objects, while the other author has his experience from teacher education. Because of our particular previous experience and present needs, we want to have both the development and user points of view. In several settings, we see the need to communicate on aspects of these learning objects, and we see a need that is not covered in the literature so far. Therefore, we will develop a classification system/taxonomy providing a comparative framework for analysis of, and communication about, learning objects for different purposes.

While we consider a broader range of purposes, our range of objects to study in this project is narrower. To be able to include subject-specific, pedagogical criteria, we decided to look at objects from one area only. Since both of the researchers are mathematicians, we chose to look at mathematics-related objects.

The elements of our study are learning objects, i.e. entities which can be used, re-used, or referenced during technology supported learning (IEEE LTSC, 2005a). We will call the subgroup of learning objects that we are studying, "VaniMaps". "VaniMaps" is an acronym we introduce in our study for $\underline{\mathbf{V}}$ isual, $\underline{\text { animated, }}$ net-based interactive $\underline{\text { Mathematical }}$ applications, provided as $\underline{\mathbf{s}}$ olitary/small learning objects. The criteria for being a VaniMaps is that the learning object is a small, stand-alone, interactive web-based resource that meets a specific mathematics learning outcome and uses visualization and graphical animation or dynamic presentation to support the learning. This pedagogically focused definition enables us to address a selection of mathematical learning objects which differ significantly from traditional learning objects in the mathematics classroom and from hyper-textual learning objects, based on text, still images or non-interactive animated pictures, film and video. The notion of VaniMaps embraces many different types of applications, for instance: (i) interactive dynamic visualizations of the proof of Pythagoras' Theorem, (ii) illustrations of mathematical objects provided to let the user explore a concept, e.g., by acting on angles to explore the angle concept, (iii) simulations visualizing how the user's variation in one variable will influence others, (iv) games to work out probabilities and consider the use of different strategies and mathematical modeling.

Our classification system could, in principle, be expanded to include looking at other subjects and other kinds of Web Based Learning resources.

\section{Literature Review}

Much of the literature on digital learning materials concerns the evaluation of them. Evaluation serves several different purposes. Nesbit, Belfer, and Vargo (2002) list eight purposes for developing effective learning object evaluation systems. In Table 1, we connect articles from the field to these purposes. 


\section{Table 1: Purposes for developing effective learning object evaluation systems, from Nesbit et al. (2002)}

\begin{tabular}{|l|l|}
\hline $\begin{array}{l}\text { 1. Ratings and qualitative assessments } \\
\text { aid individual users in searching and } \\
\text { selecting objects. }\end{array}$ & $\begin{array}{l}\text { Reeves (1994); Reeves and Harmon (1994); Lin, Choong, and } \\
\text { Salvendy (1997); Squires and Preece (1999); Vargo, Nesbit, } \\
\text { Belfer, and Archambault (2003); Gadanidis and Schindler } \\
\text { (2003); Nesbit and Li (2004); Haughey and Muirhead (2005); } \\
\text { Nokelainen (2006); Abdelhakom and Shirmohammadi (2007) }\end{array}$ \\
\hline $\begin{array}{l}\text { 2. Evaluations can provide guidance on } \\
\text { how best to use an object. }\end{array}$ & Kay and Knaack (2008); Squires and Preece (1996, 1999) \\
\hline $\begin{array}{l}\text { 3. Quality can be increased by forma- } \\
\text { tive evaluation throughout the design } \\
\text { and development stages. }\end{array}$ & $\begin{array}{l}\text { Quinn (1996); Albion (1999); Williams (2000); Baker, Green- } \\
\text { berg, and Gutwin (2002) }\end{array}$ \\
\hline $\begin{array}{l}\text { 4. Evaluation standards can drive the } \\
\text { practices of designers and develop- } \\
\text { ers. }\end{array}$ & $\begin{array}{l}\text { Kay and Knaack (2007); Lin, Choong,and Salvendy (1997); } \\
\text { Vargo, Nesbit, Belfer, and Archambault (2003); Leacock and } \\
\text { Nesbit (2007) }\end{array}$ \\
\hline $\begin{array}{l}\text { 5. Participation in evaluation activities } \\
\text { can contribute to the professional de- } \\
\text { velopment of those who work with } \\
\text { learning objects. }\end{array}$ & Williams (2000) \\
\hline $\begin{array}{l}\text { 6. Evaluation activities can build and } \\
\text { support communities of practice in } \\
\text { relation to learning objects. }\end{array}$ & Vargo, Nesbit, Belfer and Archambault (2003); Sedig and Li- \\
ang (2006)
\end{tabular}

In addition, there are also articles on the development of taxonomies without explicitly linking them to evaluation - such as Sedig and Sumner (2006), Schulmeister (2003), El Saddik (2001), Heinich, Molenda, Russell, and Smaldino (2002) and IEEE_LTSC (2005b).

Fostering communication is not pointed out as a separate purpose for developing learning object evaluation systems. Although communication is involved in both purpose 5 and 6 , these positive effects seem not to have been the main focus when the taxonomies were developed. In our project, on the other hand, the use of the taxonomies for communication is the main interest throughout the development phases. For our project, therefore, it would make sense to propose a 9th purpose: "An evaluation system may be a tool for fostering communication between clients."

Different goals necessarily lead to different fields of interest. One of Kay and Knaack's (2007) conclusions in a review of the literature is that there is a tendency that evaluation of the technology is emphasized ahead of evaluation of learning. One possible interpretation is that this is because the point of view of the developer has been emphasized more than the point of view of the user. In our project, we are consciously trying to keep several perspectives in mind at the same time.

Many researchers endeavor to reduce the complexity to a manageable set of rules, guidelines, or descriptive terms (Hinze-Hoare, 2007). In Tables 2, 3 and 4 (See Appendix), we show various approaches by different researchers: 
- Many have heuristic approaches based on theoretical models (Nielsen, 1993, 1994; Quinn, 1996; T. Reeves, \& Harmon, 1994). Albion (1999) used the sets of Nielsen and Quinn and added a set of 9 content heuristics. Squires and Preece (1999) contributed a set of 8 learning with software heuristics. Hedberg (2004) presented 7 discourses for designing multimedia.

- Vargo, Nesbit, Belfer, and Archambault (2003) also have a heuristic approach, with 10 pedagogical items for learning objects simplified by Leacock and Nesbit (2007) to 9 items. Based on these heuristics, the Learning Object Review Instrument, LORI (Nesbit, Belfer, \& Leacock, 2003), is used to evaluate the quality of learning objects, their value and needs, by rubrics, rating scales and comment fields for each item. As an online form, it may be used for individual or panel reviews.

- Horila, Nokelainen, Syvänen, and Överlund (2002) on the other hand, based their pedagogical usability criteria for digital learning material on a theoretical model and developed dimensions for subjective end-user inventory and provided 11 pedagogical dimensions. Nokelainen $(2004 ; 2005)$ provided 10 technical and 10 pedagogical dimensions. The pedagogical dimensions are operationalized in subdimensions and "pedagogical usability items" (Nokelainen, 2006). They are accommodated to the age of the evaluators in his study and stressing the subjective experience of pedagogical usability by 56 descriptive items.

Keeping the number of rules, guidelines, or descriptive terms down may be important when creating instruments for specific purposes or rating systems and checklists that should not take more than a few minutes effort to fill. In our context, however, it is more important to collect many classification statements which can be useful for different purposes than to get a "reduced system."

Olive, Makar, Hoyos, Kor, Kosheleva, and Sträßer (2008) propose a "Didactic Tetrahedron "with four vertices: Teacher, Student, Task, and Technology. It seems that even when choosing one particular perspective, in our case the fostering of communication, it will be necessary to restrict the scope of one or more of these vertices to get a manageable project. Different researches have chosen to do this in different ways.

First of all, it seems necessary to restrict the scope to one subject area. Wang (2008) claims that "the taxonomies can never be exhaustive for all disciplines, and vocabularies can be interpreted in a variety of ways depending upon the disciplines." For instance, Kay and Knaack (2008) restrict their discussion to Secondary School Mathematics.

In our project, we are limiting the Task to the mathematical content of the first 13 years of mathematics education in Norway (10 compulsory and 3 additional years). Moreover, we limit the Technology to what we call VaniMaps. The users we have worked with directly have been university-level students. Partners in the project have worked with pupils in school as well (Høivik, 2008b).

\section{Method}

We have developed the classification system in three distinct phases, of which the third is still ongoing and, in principle, everlasting:

1. Development based on literature review and discussions on examples of VaniMaps.

2. Testing the statements of the system on groups of students, analyzing the results and improving/refining statements. 
3. The use of the system for practical purposes - with ideas for improvements still being discovered.

In the first phase, the development was based on a mix of two methods: literature review and discussion on examples. In the discussion of examples, each of us tried to apply the statements to the examples and to consider whether the statements covered what we considered to be the most important characteristics of the examples. In many cases, we saw the need for new terms, leading to a discussion and a new version of the classification document before turning to the next example. The examples were carefully chosen to include VaniMaps that were different in several ways. This led to a continuous process of improvement of the classification system to include still more aspects of the VaniMaps, illustrated in Figure 1.

In the second phase, we had groups of students explore examples of VaniMaps and apply the statements to them. Involving three different courses in teacher education at two universities, we got a total of 134 full answers, two thirds of which were divided between five VaniMaps. Each answer to a questionnaire consisted of more than 200 statements, most of which could be as signed the values "True", "False" or "Don't know". This gave us both a quantitative material (the students' answers) as well as a qualitative material (students' comments during their exploration). The analysis of this material improved our understanding of how students interpreted our statements and led to more improvements. But the analysis was also valuable in making it possible for us to predict which questions would give rise to interesting discussions with students; we will come back to this in part B of the paper.

In the third (and everlasting) phase, we have used, and will use, subsets of the classification system for different purposes. We will discuss different uses in part B of this paper. In this context, however, it is important to stress that we consider every instance of use of the system as an opportunity to learn more and to develop the system further still.

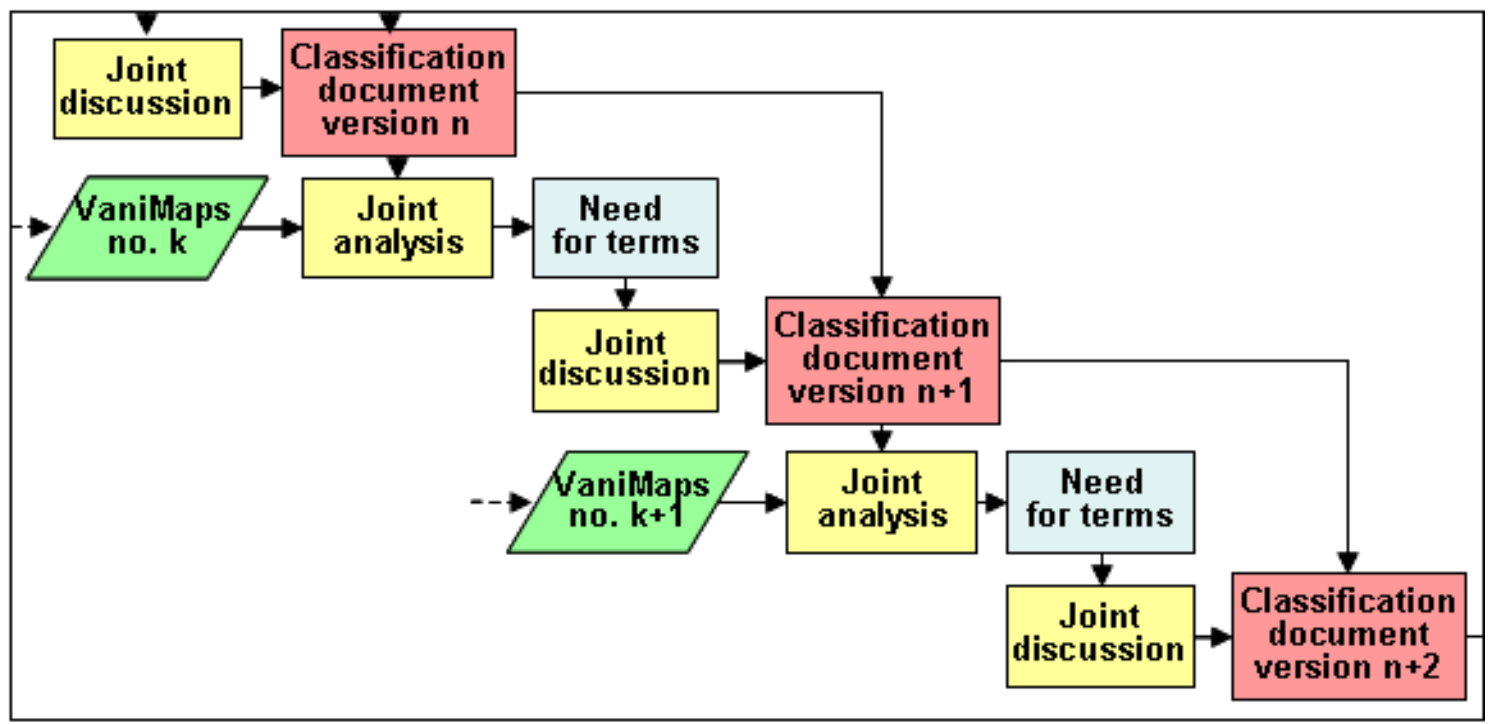

Figure 1: Steps of Analysis

\section{Discussion}

We will discuss each of the phases in a little detail. 


\section{Development based on literature review and discussions on examples of VaniMaps}

The literature review provided a variety of statements covering different perspectives. In Tables 2-6 (See Appendix), many such perspectives are shown. We were continuously looking at existing taxonomies to identify gaps - and to absorb what is fitting for VaniMaps from taxonomies of (a) pedagogical design: i.e. learning strategies, teaching design, mathematics education, intrinsic motivation, engagement; (b) technical design: i.e., graphics/audio/animation/video production, programming and performance; (c) intersections of pedagogical and technical design: i.e., information design, interactive design, metaphor and interface, and communication.

In many cases, we adapted the statements for our purposes. For instance, Gadanidis and Schindler (2003) discuss how the thinking level potential of mathematical learning objects will help users choose the most suitable alternative for any particular learning situation. We included the focus of the mathematical learning activity in our classification system. Gadanidis and Schindler call these 1) focus on recalling, mathematical facts and definitions; 2) focus on applying mathematical procedures; 3 ) focus on understanding mathematical relationships; and 4) focus on mathematical extensions and generalizations. We prefer to use a related division of mathematical knowledge which has been common in Norwegian textbooks for teacher education for a long time: facts, skills, strategies, concepts, and attitudes (i.e., Breiteig \& Venheim, 1998).

One area in which the discussion of examples supplemented the literature review was the theory of mathematics education. In looking at one particular VaniMaps, we realized that Skovsmose's theories of "landscapes of investigation" as an alternative to the "exercise discourse" (Skovsmose, 2001) came into play. These theories are influential in Scandinavian mathematics education research. One particularly important insight is that a learning resource is not a "landscape of investigation" in and of itself, but that it depends on how it is used by the teacher and the learner. We decided to include this in our classification system. We see, of course, that these concepts are not known to all user groups, but they will be useful in the context of teacher education, for instance.

\section{Testing the statements of the system on groups of students}

In the analysis of the data, we mostly looked at which statements got diverging answers from the students - and at which VaniMaps led to these diverging answers. We tried to find patterns that could give us ideas of how the statements may have been interpreted, thereby making it possible to improve the statements.

One example of a statement which led to different answers is, "Lets you choose the goal." We did originally imagine VaniMaps, for instance games, in which the user could set himself different ingame objectives. Judging by the answers from the students, however, several of them must have interpreted the statement in a different way. For instance, possibly they could have been thinking of learning goal instead. We decided to remove this statement from the classification system.

Another example is the statement, "Is a game." It became clear to us that the students have different opinions on what a game is. In our discussion, we saw that the word "game" can give associations both to a game with given rules (often with a winner) and to playing, something done for fun. While these two meanings are clearly related, they will not necessarily lead to the same answer by students faced with one particular VaniMaps. We decided to keep the statement for the time being, keeping in mind that it needs to be better defined.

It is interesting that the VaniMaps that the students disagreed about the most - "Building houses with side views" from the WisWeb project (Boon \& Brink, 2003) - is also among those we find pedagogically most interesting - and the one that the students in our case study (discussed below) 
liked the most. It seems logical that it is easier to classify objects that are more traditional than this one.

\section{The use of the system for practical purposes}

This phase will be discussed in part B.

\section{Result}

We have created a faceted taxonomy. The facets can be thought of as different axes along which VaniMaps can be described. Each facet contains a number of descriptive statements to be related to a single VaniMaps and used to describe a single property or a value, different views or aspects. Through the design process, which draws on the literature, our professional insights and students' and pupils' responses, we have designed a taxonomy that includes different perspectives.

The facets included are:

1. Concepts from mathematics education and pedagogy,

2. Target group and learning goals,

3. Type of teaching and learning activity,

4. The user's influence and control,

5. Type of interactivity,

6. Content components,

7. Dynamic way of presentation,

8. Time aspects,

9. Appearance, language and accessibility,

10. Technical concepts and

11. Overall evaluation of the quality.

In principle, the taxonomy is a permanent beta: It will never be completed, but is instead meant to be continually improved. At the current time it consists of 11 facets and 220 statements.

We periodically iterate and test, make changes and run tests against the VaniMaps, both VaniMaps that have been used before in the testing of earlier versions and VaniMaps not being used before. While we are testing and refining over time, by now 1.5 years, we are using the newest version of the taxonomy "as is" in our communication with partners and clients.

Partners in the project teams use the taxonomy with their own modifications - partly trying out other wordings or adjusting the wording to fit pupils in school - in their research and with their clients (teacher students and their pupils) and suggest changes after their analysis (Høivik, 2008b).

Through our work we have seen that the testing of the statements (in phase 2) has not only helped us improve the classification system; the data from the testing are also, for certain uses, important in themselves. We will discuss this in part B of the paper.

\section{Part B. Uses of the Classification System to Inform Clients}

\section{Introduction}

In this part of the paper, we will discuss possible uses of the classification system. We claim that it can be used to:

(a) facilitate communication between the orderer and the developer, 
(b) initiate discussions on VaniMaps in teacher education,

(c) analyze and choose between different VaniMaps for teaching and learning activities,

(d) establish a database for VaniMaps labeled using classification statements.

Here, we will first discuss all of these, and then give an example of an actual teaching sequence in teacher education.

\section{(a) Use to facilitate communication between the orderer and the developer}

Developing rich and complex interactive learning objects is slow and expensive. There is a need to foster efficient and effective communication between customers that order and describe essential characteristics of new VaniMaps and potential producers that are supposed to develop working solutions. Precise terms for thematic discussions would help to avoid unnecessary intricacy in an already complex development situation (Littlejohn, 2003).

The MathWiz project is within the framework of TermS, Terminologies as Educational Resources and Mediators (Høivik, Ellingham, Gang, Retvik, \& Strøm, 2007). It is conducted through a partnership comprising Oslo University College and University of Agder in Norway and Beijing Normal University in China (Høivik, 2008a). A part of the MathWiz project aims to build a design pattern for collaborative development of VaniMaps related to a taxonomy that describes VaniMaps for several grade levels in order to improve production of such materials (Høivik, 2008b).

\section{(b) Use to initiate discussions on VaniMaps in teacher education}

As any teacher could attest, differences of opinion may lead to interesting discussions which again may lead to learning. However, in the traditional classrooms, students may find it more convenient to sit back and listen to the lecturer's talk than to actively engage with it. We see an opportunity for using the classification system to engage the students and provoke discussions. Most of this part of the paper is devoted to the discussion of a case study of this.

\section{(c) Use to analyze and choose between VaniMaps for teaching and learning activities}

In our view, a short checklist cannot be well suited for the variety of teachers and learning situations that exist. A broad classification system, in which the teacher can pick and choose which statements to consider, is necessary. Teachers will want digital materials that are suited to their own teaching practice and, therefore, need to take into account different theories of teaching, for instance. Which statements are relevant will also depend on the subject taught.

\section{(d) Use to establish a database for VaniMaps labeled using classification statements}

One major reason teachers give for not using VaniMaps in the mathematics classroom is the difficulty of finding suitable resources on the net. Therefore, there are several initiatives to collect and make more easily available resources from different sources. The search criteria in such collections have been of different kinds, but often only the topic and the level have been available search options. This is not enough, considering the breadth of considerations that should be involved in choosing VaniMaps for use in the classroom.

There are initiatives to remedy this. Nokelainen (2006) discusses a computer application called the eValuator, in which users provide answers to selected questions about each material. These questions are then the basis for the search algorithm. It also lets the users add new links to digital 
learning materials to the database. Nokelainen's system would be an improvement. However, there is potential for utilizing the user input even more by, for instance, automatically analyzing what users search for and prioritize improving the evaluations on these dimensions.

\section{Research and Development Issues}

In the rest of this paper, we will develop on point (c) above: can the classification system we have developed be used to enrich teaching about VaniMaps in teacher education?

\section{Method}

This is a case study in which the goal is to design a teaching segment where the classification system was used as a way of fostering discussion in the teaching of VaniMaps in teacher education. Various methods are applied to collect data.

In a course on "ICT and learning" at a Norwegian university, there is to be a three-hour segment on "digital learning resources" early in the course. This particular topic has often been taught as a lecture with examples shown by the teacher. The 13 students have different backgrounds; some of them are from teacher education while some are from other areas. The teachers normally in charge of the class describe them as "quiet" and difficult to engage in discussions.

Draper and Brown (2004) argue that "electronic voting systems" in lectures "makes far more students actually think through and decide on an answer." The anonymity provided means that "few students select the 'don't know' response option." Moreover, students valued the feedback the teacher gave based on the student responses. Draper and Brown point to two particularly promising pedagogical approaches: "interactive engagement" (instigating peer discussions) and "contingent teaching" (adjusting the lecture based on answers received during the lecture). Nadelhoffer and Nahmias (2008) argue for the use of polling as a pedagogical tool in teaching philosophy. Several of the benefits they mention seem to be just as valid for teaching digital learning resources: The use of polling "suggests to students that their opinions are important", "initiates discussion and debate" and "allows you to get to know your students and allows them to get to know each other."

Our teaching sequence is divided into sections, each involving one VaniMaps. Each section includes a small introduction by the lecturer-researcher. Then, for each VaniMaps, the students work on it for a while, fill in a questionnaire with a set of classification statements, and then have a discussion based on the answers they have given. In the discussion, we pay particular attention to divergent answers.

The design of our teaching sequence incorporates these main ideas:

- The teacher makes a selection of VaniMaps and prepares an electronic questionnaire to each of them with a range of classification statements from the taxonomy.

- The VaniMaps and the statements are chosen based on the previous studies, to ensure both that our teaching goals are met and that the students will be likely to answer the questions differently, so that interesting discussions can appear.

- The lecture is divided into sections, one for each VaniMaps. Each section is preceded by a small introduction from the teacher. The students explore the VaniMaps and then make their judgments on the VaniMaps by filling in the survey.

- The results from each survey are immediately presented on the screen by the teacher, and important points are discussed. 
In the teaching sequence carried out, we chose 7 VaniMaps each with 5-20 statements from the current taxonomy for a 3 hours lecture.

The following data were collected:

- the preparation documents, including the lecturer-researcher's notes in advance, the email correspondence between the researchers, and the information sent to the students in advance.

- the surveys from the students, as well as notes from the lecturer-researcher written at the time. In the last survey, the students were also asked questions on how they perceived the outcome of the lecture.

- reflections from the lecturer-researcher written the same day.

The analysis of the data has been performed by both the lecturer-researcher and the non-present researcher. This will improve the validity of the analysis, compared to only one researcher analyzing.

\section{Discussion}

In our experience, opportunities for discussions on central points of a topic are valuable in education. In traditional lectures, these opportunities will often be rare - the students may noddingly accept everything that the lecturer says and may be hard to engage. We will analyze our material to see to what extent the teaching sequence presented opportunities for discussions and how the discussions cast light on the topic in question.

It is important to stress that our goal is not a pre-defined teaching segment in which everything is predictable. Our goal is a teaching segment in which there arise many opportunities for discussion. As stated in part A, some of these opportunities will be predicted by us based on previous student answers. We will give three examples of this. Other opportunities arise when the students give answers we did not expect. As in all teaching, some of these opportunities will be used while others will not, based on a complex set of considerations by the teacher, i.e., reflection-in-action (Schön, 1983).

One of the VaniMaps included was the "Kids and cookies" application from the Center for Technology and Teacher Education at the University of Virginia (Garofalo, Garofalo, Sharp, Summers, \& Williamson, 2002). In our previous studies, we saw that students disagreed on which level this VaniMaps was suited for, and we decided to include statements concerning suitability for children of different age groups in order to provoke this discussion. Now, 8 students agreed that the VaniMaps was suited for lower elementary school (age 6-9), while 4 disagreed. Similarly, 5 students agreed that it was suited for lower secondary school (age 13-16), while 6 disagreed. The teacher-researcher saw this as an opportunity for discussion and asked the students for their reasons. It appeared that the students had many different concerns in mind when answering this question. Some answered based on the mathematics involved, others based on the language (as the language is English, it will not be suited for small children in Norway), others still on the design (although the mathematics involved is still a problem for pupils in lower secondary school, the students argued that the design is too childish to be used there). Based on these simple questions, the students themselves made clear the breadth of concerns involved when evaluating VaniMaps. Choosing this particular VaniMaps as the first in the sequence of examples made the students catch this key point quite early. The teacher-researcher then added a few more points to the discussion.

Another VaniMaps we had chosen for inclusion was the "Building houses with side views" from the WisWeb project (Boon \& Brink, 2003). Again, based on previous studies we anticipated that 
the students would have different opinions on the statement "Helps me learn mathematics." They did; 7 students agreed while 5 disagreed. When the lecturer-researcher asked the students about this, it turned out that it was difficult for the students to pinpoint what mathematics was involved. One student argued that logic was involved, and that logic is mathematics, while another argued that geometry was involved. Still others claimed that mathematics was involved, but could not describe it further. The discussion may have contributed to an understanding that it is useful to be more precise when considering which mathematics a VaniMaps can contribute to the learning of.

Yet another finding from our previous studies is that students tend to disagree when asked whether a certain VaniMaps "is a game." We therefore included this statement in the questionnaire for the VaniMaps "Linear equations, practice" from the WisWeb project (Boon, 2003). Again, the students disagreed with each other as predicted: 4 students agreed that the VaniMaps was a game, while 6 students disagreed. This led to a short discussion on what the definition of "game" should be for our purposes - is the awarding of points sufficient, or are there other important characteristics (for instance "fun")?

These are just three examples of discussion opportunities that arose based on our ideas of how the students would answer. In the teaching sequence, there were more such opportunities than the lecturer-researcher could possibly follow up on. And still, two (out of seven) VaniMaps had to be skipped for lack of time. The design of the teaching sequence seems to have contributed to more discussions than can usually be expected from this group of students. Thus, we have managed to create "interactive engagement" (Draper \& Brown, 2004) by instigating discussions through polling. We have also included "contingent teaching" by teaching according to the needs seen in the answers and the discussion.

In a questionnaire at the end of the lecture, students were asked what they had learned about digital learning resources in the lecture. The group of students is obviously too small to draw conclusions based on their answers, but it may be worth listing the different points mentioned:

- learning about the wide variety of learning resources

- learning to evaluate

- $\quad$ seeing the use of VaniMaps

- seeing that some VaniMaps are suited to one particular age group, others for several

- seeing that both the design, layout and the number of choices available are important

- seeing that this can be fun for the pupil

- learning about "exercise discourse" and "landscape of investigation".

\section{Limitations and Directions for Further Research}

We have looked at a subgroup of learning objects, in order to be able to include discussions from the area of mathematics education. This obvious limitation means that the classification system in itself is not interesting for users in other fields.

In our project we have not tried to develop the definitive classification system for VaniMaps, but to describe a process by which we can develop a classification system that is good enough for fostering communication in certain contexts. Moreover, the classification system we have developed has been tested on a fairly limited group of students, and should be developed further.

Our case study is small. The lecture in question will probably be institutionalized at the university, which will give us more opportunities for further studies. More case studies should be done in other settings to see whether the ideas are generalizable. 
Our process involved testing statements in groups of students and then using these test results to choose which statements to include in the teaching. This process may seem too cumbersome to be used in a practical teaching setting. However, in a setting where the same teaching sequence is to be repeated every year or even more often, our process can be adjusted so that the answers from one group of students are used to choose answers for the next group.

In the case study, we have looked at how our design provides opportunities for discussions instead of looking at students' learning. Testing of student learning would lead to a quite different research design.

\section{Conclusion}

In part A of this paper, we discussed a process of developing a taxonomy for learning objects we call VaniMaps. The purpose was to get a collection of statements as a tool for fostering communication between clients. In part B of the paper, we used both the taxonomy and the data collected during the development, to design a teaching segment in which the classification system was used. We have shown how careful selection of VaniMaps and statements created opportunities for discussion among future teachers on how VanMaps may stimulate learning of mathematics.

\section{References}

Abdelhakim, M. N. A., \& Shirmohammadi, S. (2007). A web-based group decision support system for the selection and evaluation of educational multimedia. Proceedings of the International Workshop on Educational Multimedia and Multimedia Education, Augsburg.

Albion, P. R. (1999). Heuristic evaluation of educational multimedia: From theory to practice. Retrieved October 15, 2008, from http://www.usq.edu.au/users/albion/papers/ascilite99.html

Baker, K., Greenberg, S., \& Gutwin, C. (2002). Empirical development of a heuristic evaluation methodology for shared workspace groupware. Proceedings of the 2002 ACM Conference on Computer Supported Cooperative Work (CSCW' 02 ) New Orleans, Louisiana, USA.

Boon, P. (Producer). (2003) Linear equations, practice. Retrieved October 15, 2008, from http://www.fi.uu.nl/toepassingen/02062/toepassing_wisweb.en.html

Boon, P., \& Brink, J. v. d. (Producer). (2003) Building houses with side views. Retrieved October 15, 2008, from http://www.fi.uu.nl/toepassingen/02015/toepassing_wisweb.en.html

Breiteig, T., \& Venheim, R. (1998). Matematikk for lcerere. Oslo: Tano Aschehoug.

Draper, S. W., \& Brown, M. I. (2004). Increasing interactivity in lectures using an electronic voting system. Journal of Computer Assisted Learning, 20, 81-94.

El Saddik, A. (2001). Interactive multimedia learning. Berlin: Springer.

Gadanidis, G., \& Schindler, K. (2003). Learning objects and the level of mathematical thinking. Proceedings of E-Learn 2003 - World Conference on E-learning in Corporate, Government, Healthcare, and Higher Education, 478-485.

Garofalo, L., Garofalo, J., Sharp, B., Summers, T., \& Williamson, S. (Producer). (2002). Kids and cookies. Retrieved October 15, 2008, from http://www.teacherlink.org/content/math/interactive/flash/kidsandcookies/kidcookie.php

Haughey, M., \& Muirhead, B. (2005). Evaluating learning objects for schools. e-Journal of Instructional Science and Technology, 8(1). Retrieved October 15, 2008, from http://www.usq.edu.au/electpub/ejist/docs/vol8_no1/fullpapers/Haughey_Muirhead.pdf

Hedberg, J. (2004). Designing multimedia: Seven discourses. Cambridge Journal of Education, 34(2), 241256. 
Heinich, R., Molenda, M., Russell, J. D., \& Smaldino, S. E. (2002). Instructional media and technologies for learning (7th ed.). New York: Prentice Hall.

Hinze-Hoare, V. (2007). The review and analysis of human computer interaction (HCI) principles. Retrieved October 15, 2008, from http://arxiv.org/ftp/arxiv/papers/0707/0707.3638.pdf

Horila, M., Nokelainen, P., Syvänen, A., \& Överlund, J. (2002). Criteria for the pedagogical usability, version 1.0. Hämeenlinna, Finland: Häme Polytechnic and University of Tampere.

Høivik, H. (2008a). Collaboration with Chinese institutions. Progress report 2007. Oslo University College.

Høivik, H. (2008b). A design pattern for collaborative development of game-like learning objects. E-Learn 2008 - World Conference on E-learning in Corporate, Government, Healthcare, and Higher Education, 2733-2740.

Høivik, H., Ellingham, B., Gang, C., Retvik, J., \& Strøm, E. (2007). Leksjoner med leksikaler [Lessons with lexicals]. Paper presented at the Nokobit.

IEEE_LTSC (Institute of Electrical and Electronic Engineers, Learning Technology Standards Committee) (2005a). The learning object metadata standard. Retrieved March 1, 2008, from IEEE Learning Technology Standards Committee Web site: http://www.ieeeltsc.org/working-groups/wg12LOM/lomDescription

IEEE_LTSC (Institute of Electrical and Electronic Engineers, Learning Technology Standards Committee) (2005b). IEEE P1484.12.3, Draft 8. Draft standard for learning technology-Extensible markup language (XML) schema definition language binding for learning object metadata. New York: Institute of Electrical and Electronics Engineers Standards Association.

Kay, R. H., \& Knaack, L. (2007). Evaluating the learning in learning objects. Open Learning, 22(1), 5-28.

Kay, R. H., \& Knaack, L. (2008). Investigating the use of learning objects for secondary school mathematics. Interdisciplinary Journal of E-Learning and Learning Objects, 4, 269-289. Retrieved October 15, 2008, from http://ijklo.org/Volume4/IJELLOv4p269-289Kay.pdf

Leacock, T. L., \& Nesbit, J. C. (2007). A framework for evaluating the quality of multimedia learning resources. Educational Technology \& Society, 10(2), 44-59.

Lin, H. X., Choong, Y.-Y., \& Salvendy, G. (1997). A proposed index of usability: A method for comparing the relative usabilities of different software systems. Behaviour and Information Technology, 16(4/5), 267-278.

Littlejohn, A. (2003). Supporting sustainable e-learning. ALT-J, 11(3), 88-102.

Nadelhoffer, T., \& Nahmias, E. (2008). Polling as pedagogy: Experimental philosophy as a valuable tool for teaching philosophy. Teaching Philosophy, 31(1), 39-58.

Nesbit, J. C., Belfer, K., \& Leacock, T. (2003). Learning object review instrument (LORI). E-Learning Research and Assessment Network.

Nesbit, J. C., Belfer, K., \& Vargo, J. (2002). A convergent participation model for evaluation of learning objects. Canadian Journal of Learning and Technology, 28(3), 105-120. Retrieved October 15, 2008, from http://www.cjlt.ca/index.php/cjlt/article/viewArticle/110/103

Nesbit, J. C., \& Li, J. (2004). Web-based tools for learning object evaluation. Paper presented at the International Conference on Education and Information, 2, 334-339.

Nielsen, J. (1993). Usability engineering. Boston, MA: Academic Press.

Nielsen, J. (1994). Heuristic evaluation. In J. Nielsen \& R. L. Mack (Eds.), Usability inspection methods. New York: John Wiley \& Sons.

Nokelainen, P. (2004). Conceptual definition of the technical and pedagogical usability criteria for digital learning material. Paper presented at the World Conference on Educational Multimedia, Hypermedia and Telecommunications 2004, Lugano, Switzerland. 4249-4254. 
Nokelainen, P. (2005). The technical and pedagogical usability criteria for digital learning material. Paper presented at the World Conference on Educational Multimedia, Hypermedia and Telecommunications 2005, Montreal, Canada. 1011-1016.

Nokelainen, P. (2006). An empirical assessment of pedagogical usability criteria for digital learning material with elementary. Educational Technology and Society, 9(2), 178-197. Retrieved October 15, 2008, from http://www.ifets.info/journals/9_2/ets 9 2.pdf

Olive, J., Makar, K., Hoyos, V., Kor, L. K., Kosheleva, O., \& Sträßer, R. (2008). Mathematical knowledge and practices resulting from access to digital technologies. Technology Revisited. Dortrecht: Kluwer.

Quinn, C. N. (1996). Pragmatic evaluation: Lessons from usability. Retrieved October 15, 2008, from http://www.ascilite.org.au/conferences/adelaide96/papers/18.html

Reeves, T., \& Harmon, S. W. (1994). Systematic evaluation procedures for interactive multimedia for education and training. In S. Reisman (Ed.), Multimedia computing: Preparing for the 21 century (pp. IX, 608 s.). Harrisburg, PA: Idea Group Publishing.

Reeves, T. C. (1994). Evaluating what really matters in computer-based education. Paper presented at Computer Education: New Perspectives, Perth. 219-246.

Schulmeister, R. (2003). Taxonomy of multimedia component interactivity. A contribution to the current metadata debate. Studies in Communication Sciences, [Studi di scienze della communicazione], 61-80. Retrieved October 15, 2008, from http://www.izhd.uni-hamburg.de/pdfs/Interactivity.pdf

Schön, D. A. (1983). The reflective practitioner: How professionals think in action. New York: Basic Books.

Sedig, K., \& Liang, H.-N. (2006). Interactivity of visual mathematical representations: Factors affecting learning and cognitive processes. Journal of Interactive Learning Research, 17(2), 179-212.

Sedig, K., \& Sumner, M. (2006). Characterizing interaction with visual mathematical representations. International Journal of Computers for Mathematical Learning, 11(1), 1-55.

Skovsmose, O. (2001). Landscapes of investigation. ZDM, 33(4), 123-132.

Squires, D., \& Preece, J. (1996). Usability and learning: Evaluating the potential of educational software. Computers \& Education, 27(1), 15-22.

Squires, D., \& Preece, J. (1999). Predicting quality in educational software: Evaluating for learning, usability and the synergy between them. Interacting with Computers, 11(5), 467-483.

Vargo, J., Nesbit, J. C., Belfer, K., \& Archambault, A. (2003). Learning object evaluation: Computermediated collaboration and inter-rater reliability. International Journal of Computers and Applications, 25(3), 198-205.

Wang, S. (2008). Ontology of learning objects repository for pedagogical knowledge sharing. Interdisciplinary Journal of E-Learning and Learning Objects, 4, 1-12. Retrieved October 15, 2008, from http://ijello.org/Volume4/IJKLOv4p001-012Wang200.pdf

Williams, D. D. (2000). Evaluation of learning objects and instruction using learning objects. Retrieved October 15, 2008, from http://reusability.org/read/chapters/williams.doc 
Appendix. Tables $2-6$

Table 2: Summary of interface heuristics and technical usability attributes

\begin{tabular}{|c|c|c|c|}
\hline Nielsen (1993) & Nielsen (Nielsen, 1994) & $\begin{array}{l}\text { Reeves and } \\
\text { Harmon (1994) }\end{array}$ & Nokelainen $(2004,2005)$ \\
\hline Usability Heuristics & Usability Heuristics & $\begin{array}{l}\text { Interface dimen- } \\
\text { sions }\end{array}$ & $\begin{array}{l}\text { Technical usability of } \\
\text { digital learning materials }\end{array}$ \\
\hline $\begin{array}{l}\text { 01. Simple and natural } \\
\text { dialogue } \\
\text { 02. Speak the user's } \\
\text { language } \\
\text { 03. Minimize the user's } \\
\text { memory load } \\
\text { 04. Consistency } \\
\text { 05. Feedback } \\
\text { 06. Clearly marked } \\
\text { exits } \\
\text { 07. Shortcuts } \\
\text { 08. Good error mes- } \\
\text { sages } \\
\text { 09. Prevent errors } \\
\text { 10. Help and documen- } \\
\text { tation }\end{array}$ & $\begin{array}{l}\text { 01. Aesthetic and minimalist de- } \\
\text { sign } \\
\text { 02. Match between system and } \\
\text { the real world } \\
\text { 03. Recognition rather than recall } \\
\text { 04. Consistency and standards } \\
\text { 05. Visibility of system status } \\
\text { 06. User control and freedom } \\
\text { 07. Flexibility and efficiency of } \\
\text { use } \\
\text { 08. Help users recognize, diag- } \\
\text { nose, and recover from errors } \\
\text { 09. Error prevention } \\
\text { 10. Help and Documentation }\end{array}$ & $\begin{array}{l}\text { 01. Ease of use } \\
\text { 02. Navigation } \\
\text { 03. Cognitive load } \\
\text { 04. Mapping } \\
\text { 05. Screen Design } \\
\text { 06. Knowledge } \\
\text { Space Compati- } \\
\text { bility } \\
\text { 07. Information } \\
\text { Presentation } \\
\text { 08. Media Integra- } \\
\text { tion } \\
\text { 09. Aesthetics } \\
\text { 10. Overall func- } \\
\text { tionality }\end{array}$ & $\begin{array}{l}\text { 01. Accessibility } \\
\text { 02. Learnability and } \\
\text { memorability } \\
\text { 03. User control } \\
\text { 04. Help } \\
\text { 05. Graphical layout } \\
\text { 06. Reliability } \\
\text { 07. Consistency } \\
\text { 08. Efficiency of use } \\
\text { 09. Memory load } \\
\text { 10. Errors }\end{array}$ \\
\hline
\end{tabular}

Table 3: Summary of the pedagogical usability criteria research, part 1

\begin{tabular}{|c|c|c|c|}
\hline $\begin{array}{l}\text { Reeves and Harmon } \\
\text { (1994), Reeves (1994) }\end{array}$ & Quinn (1996) & Albion (1999) & $\begin{array}{l}\text { Squires and Preece } \\
(1999)\end{array}$ \\
\hline Pedagogical dimensions & $\begin{array}{l}\text { Educational design heu- } \\
\text { ristics }\end{array}$ & Content Heuristics & $\begin{array}{l}\text { Learning with software } \\
\text { heuristics }\end{array}$ \\
\hline $\begin{array}{l}\text { 01. Epistemology } \\
\text { 02. Pedagogical Philosophy } \\
\text { 03. Underlying Psychology } \\
\text { 04. Goal orientation } \\
\text { 05. Instructional Sequenc- } \\
\text { ing }\left(^{*}\right) \\
\text { 06. Experiential Value } \\
\text { (Authenticity) } \\
\text { 07. Role of Instructor } \\
\text { 08. Value of Errors } \\
\text { 09. [Origin of] Motivation } \\
\text { 10. Structure (*) } \\
\text { 11. Accommodation of } \\
\text { Individual Differences } \\
\text { (Scaffolding) } \\
\text { 12. Learner Control } \\
\text { 13. User activity } \\
\text { 14. Cooperative Learning } \\
(*) \text { Reeves (2004): Flexi- } \\
\text { bility; Cultural Sensitivity }\end{array}$ & $\begin{array}{l}\text { 01. Clear goals and ob- } \\
\text { jectives } \\
\text { 02. Context meaningful } \\
\text { to domain and learner } \\
\text { 03. Content clearly and } \\
\text { multiply represented, } \\
\text { and multiply naviga- } \\
\text { ble } \\
\text { 04. Activities scaffolded } \\
\text { 05. Elicit learner under- } \\
\text { standings } \\
\text { 06. Formative evaluation } \\
\text { 07. Performance should } \\
\text { be 'criteria- } \\
\text { referenced' } \\
\text { 08. Support for transfer- } \\
\text { ence and acquiring } \\
\text { 'self-learning' skills }\end{array}$ & $\begin{array}{l}\text { 01. Establishment of } \\
\text { context } \\
\text { 02. Relevance to profes- } \\
\text { sional practice } \\
\text { 03. Representation of } \\
\text { professional re- } \\
\text { sponses to issues } \\
\text { 04. Relevance of refer- } \\
\text { ence materials } \\
\text { 05. Presentation of video } \\
\text { resources } \\
\text { 06. Assistance is suppor- } \\
\text { tive rather than pre- } \\
\text { scriptive } \\
\text { 07. Materials are engag- } \\
\text { ing } \\
\text { 08. Presentation of re- } \\
\text { sources } \\
\text { 09. Overall effectiveness } \\
\text { of materials }\end{array}$ & $\begin{array}{l}\text { 01. Match between de- } \\
\text { signer and learner } \\
\text { models } \\
\text { 02. Navigational fidelity } \\
\text { 03. Appropriate levels of } \\
\text { learner control } \\
\text { 04. Prevention of periph- } \\
\text { eral cognitive errors } \\
\text { 05. Understandable and } \\
\text { meaningful symbolic } \\
\text { representation } \\
\text { 06. Support personally } \\
\text { significant approaches } \\
\text { to learning } \\
\text { 07. Strategies for the } \\
\text { cognitive error recog- } \\
\text { nition, diagnosis and } \\
\text { recovery cycle } \\
\text { 08. Match with the cur- } \\
\text { riculum }\end{array}$ \\
\hline
\end{tabular}


Table 4: Summary of the pedagogical usability criteria research, part 2

\begin{tabular}{|c|c|c|c|}
\hline $\begin{array}{l}\text { nen, Syvänen } \\
\text { 2002) }\end{array}$ & $\begin{array}{l}\text { Vargo, Nesbit, Belfer and } \\
\text { Archambault (2003) }\end{array}$ & $\begin{array}{l}\text { Nesbit, Belfer and } \\
\text { Leacock (2003) }\end{array}$ & $\begin{array}{l}\text { Nokelainen (2004, } \\
\text { 2005, 2006) }\end{array}$ \\
\hline & & $\begin{array}{l}\text { edagogical heuris- } \\
\text { cs of Learning Ob- } \\
\text { cts }\end{array}$ & erial \\
\hline \begin{tabular}{|l|} 
01. Learnability \\
02. Graphics and layout \\
03. Technical requirements \\
04. Intuitive efficiency \\
05. Suitability for different \\
$\quad$ learners and different \\
situations \\
06. Ease of use: Technical and \\
pedagogical approach \\
07. Interactivity \\
08. Objectiveness \\
09. Sociality \\
10. Motivation \\
11. Added value for teaching
\end{tabular} & $\begin{array}{l}\text { 01. Presentation Aesthetics } \\
\text { 02. Presentation Design for } \\
\text { Learning } \\
\text { 03. Accuracy of Content } \\
\text { 04. Support for Learning } \\
\text { Goals } \\
\text { 05. Motivation } \\
\text { 06. Interaction: Usability } \\
\text { 07. Interaction: Feedback } \\
\text { and Adaption } \\
\text { 08. Reusability } \\
\text { 09. Standards Compliance } \\
\text { 10. Accessibility }\end{array}$ & $\begin{array}{l}\text { 01. Content Quality } \\
\text { 02. Learning Goal } \\
\text { Alignment } \\
\text { 03. Feedback and } \\
\text { Adaptation } \\
\text { 04. Motivation } \\
\text { 05. Presentation De- } \\
\text { sign } \\
\text { 06. Interaction Us- } \\
\text { ability } \\
\text { 07. Accessibility } \\
\text { 08. Reusability } \\
\text { 09. Standards Com- } \\
\text { pliance }\end{array}$ & $\begin{array}{l}\text { 01. Learner control } \\
\text { 02. Learner Activity } \\
\text { 03. Cooperative/ col- } \\
\quad \text { laborative learning } \\
\text { 04. Goal orientation } \\
\text { 05. Applicability } \\
\text { 06. Added value for } \\
\quad \text { learning } \\
\text { 07. Motivation } \\
\text { 08. Valuation of previ- } \\
\text { ous knowledge } \\
\text { 09. Flexibility } \\
\text { 10. Feedback }\end{array}$ \\
\hline
\end{tabular}

Table 5: Frameworks, types and levels for interactivity and interaction

\begin{tabular}{|c|c|c|c|}
\hline Schulmeister (2003) & EI Saddik (2001) & Sedig and Liang (2006) & $\begin{array}{l}\text { Sedig and Sumner } \\
(\mathbf{2 0 0 6 )}\end{array}$ \\
\hline $\begin{array}{l}\text { Level of interactivity of- } \\
\text { fered to the user }\end{array}$ & $\begin{array}{l}\text { Degree of interaction } \\
\text { with a visualization sys- } \\
\text { tem }\end{array}$ & $\begin{array}{l}\text { Interactivity framework } \\
\text { for analyzing mathemati- } \\
\text { cal presentations }\end{array}$ & $\begin{array}{l}\text { Interaction framework for } \\
\text { characterizing mathe- } \\
\text { matical presentations }\end{array}$ \\
\hline $\begin{array}{l}\text { 01. Viewing objects and } \\
\text { receiving } \\
\text { 02. Watching and receiv- } \\
\text { ing multiple represen- } \\
\text { tations } \\
\text { 03. Varying the form of } \\
\text { representation. } \\
\text { 04. Manipulating the } \\
\text { component content } \\
\text { 05. Constructing the ob- } \\
\text { ject or representation } \\
\text { contents. } \\
\text { 06. Constructing the Ob- } \\
\text { ject or Contents of the } \\
\text { Representation and } \\
\text { Receiving Intelligent } \\
\text { Feedback from the } \\
\text { System through Ma- } \\
\text { nipulative Action. }\end{array}$ & $\begin{array}{l}\text { 01. Still images } \\
\text { 02. Animated Pictures } \\
\text { 03. Visualization with } \\
\text { display adjustments } \\
\text { 04. Visualization selec- } \\
\text { tion and arrangement } \\
\text { capabilities (VCR) } \\
\text { 05. Visualization with } \\
\text { changing input, zoom- } \\
\text { ing and panning } \\
\text { 06. Visualization with } \\
\text { interactive decision } \\
\text { points, e.g. changing } \\
\text { data while running } \\
\text { 07. Visualization gener- } \\
\text { ated by students }\end{array}$ & $\begin{array}{l}\text { 01. Affordance } \\
\text { 02. Cognitive offloading } \\
\text { 03. Constraints } \\
\text { 04. Distance } \\
\text { 05. Epistemic appropri- } \\
\quad \text { ateness } \\
\text { 06. Feedback } \\
\text { 07. Flexibility } \\
\text { 08. Flow } \\
\text { 09. Focus } \\
\text { 10. Involvement } \\
\text { 11. Scaffolding } \\
\text { 12. Time-Space commu- } \\
\text { nication }\end{array}$ & $\begin{array}{l}\text { Basic-interaction: } \\
\text { 01. Conversing } \\
\text { 02. Manipulating } \\
\text { 03. Navigating } \\
\text { Task-based } \\
\text { interaction: } \\
\text { 01. Animating } \\
\text { 02. Annotation } \\
\text { 03. Chunking } \\
\text { 04. Composing } \\
\text { 05. Cutting } \\
\text { 06. Filtering } \\
\text { 07. Fragmenting } \\
\text { 08. Probing } \\
\text { 09. Rearranging } \\
\text { 10. Picturing } \\
\text { 11. Scoping } \\
\text { 12. Searching }\end{array}$ \\
\hline
\end{tabular}


Table 6: Further examples, including other aspects in the literature

\begin{tabular}{|c|c|c|c|}
\hline $\begin{array}{l}\text { Draft Standard for } \\
\text { LOM } 1.3 \text { (IEEE_LTSC, } \\
\text { 2005b) }\end{array}$ & $\begin{array}{l}\text { Draft Standard for } \\
\text { LOM 1.3 (IEEE_LTSC, } \\
\text { 2005b) }\end{array}$ & $\begin{array}{l}\text { Heinich, Molenda, Rus- } \\
\text { sell and Smaldino (2002) }\end{array}$ & $\begin{array}{l}\text { Gadanidis and } \\
\text { Schindler (2003) }\end{array}$ \\
\hline Types of interactivity & Learning resource types & $\begin{array}{l}\text { Types of instructional } \\
\text { methods in pedagogical } \\
\text { design }\end{array}$ & $\begin{array}{l}\text { Thinking level potential } \\
\text { of mathematical learning } \\
\text { objects }\end{array}$ \\
\hline $\begin{array}{l}\text { 01. Active } \\
\quad \text { (learning by doing) } \\
\text { 02. Expositive } \\
\quad \text { (passive learning) } \\
\text { 03. } \text { Mixed }\end{array}$ & $\begin{array}{l}\text { 01. Exercise } \\
\text { 02. Simulation } \\
\text { 03. Questionnaire } \\
\text { 04. Diagram } \\
\text { 05. Figure } \\
\text { 06. Graph } \\
\text { 07. Index } \\
\text { 08. Slide } \\
\text { 09. Table } \\
\text { 10. Narrative text } \\
\text { 11. Exam } \\
\text { 12. Experiment } \\
\text { 13. Problem statement } \\
\text { 14. Self assessment } \\
\text { 15. Lecture }\end{array}$ & $\begin{array}{l}\text { 01. Presentation } \\
\text { 02. Demonstration } \\
\text { 03. Discussion } \\
\text { 04. Drill-and-practice } \\
\text { 05. Tutorial } \\
\text { 06. Cooperative learning } \\
\text { 07. Gaming } \\
\text { 08. Simulation } \\
\text { 09. Discovery } \\
\text { 10. Problem solving }\end{array}$ & $\begin{array}{l}\text { 01. Focus on recalling } \\
\text { mathematical facts } \\
\text { and definitions } \\
\text { 02. Focus on applying } \\
\text { mathematical proce- } \\
\text { dures } \\
\text { 03. Focus on understand- } \\
\text { ing mathematical rela- } \\
\text { tionships } \\
\text { 04. Focus on mathemati- } \\
\text { cal extensions and } \\
\text { generalizations }\end{array}$ \\
\hline
\end{tabular}

\section{Biographies}

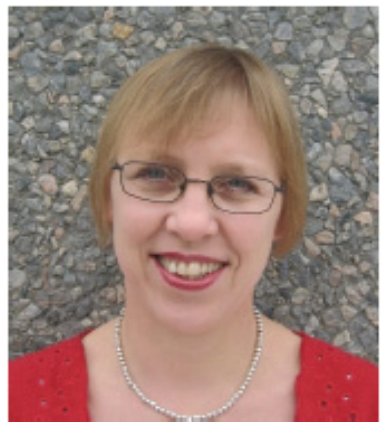

Cornelia Brodahl is an Assistant Professor at the Faculty of Engineering and Science at the University of Agder, Kristiansand (Norway), from 2001. She received the master degree in Mathematics from the University of Münster (Germany) in 1979 and is currently working towards a professional doctorate. She has been in the teaching profession since 1980 and worked as system analyst in industry in 19982001. Her research and teaching interests include ICT and learning, and Professional ICT Didactics. Main areas of expertise and interest are ICT supported learning, digital teaching aids, pedagogical web design, and didactical animations in mathematics.

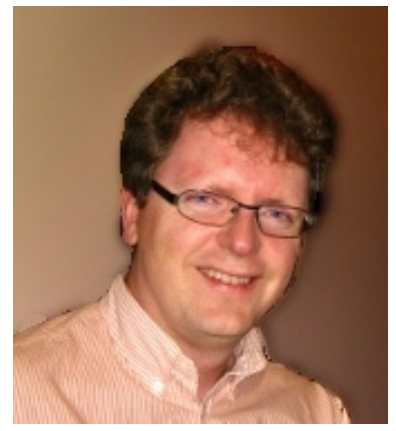

Bjørn Smestad is an Assistant Professor at the Faculty of Education and International Studies at Oslo University College (Norway). He received the master degree in Mathematics from the University of Oslo in 1995 and is currently working towards a professional doctorate. He has been working in teacher education since 1998. His research interests include history of mathematics and ICT in a classroom context. He has been the co-editor of the HPM Newsletter since 2004. 